\title{
Measures in the Area of Sales in Company Crisis
}

\author{
Drago Dubrovski \\ International School for Social and Business Studies, Mariborska, Celje, Slovenia
}

\section{Email address:}

drago.dubrovski@mfdps.si

\section{To cite this article:}

Drago Dubrovski. Measures in the Area of Sales in Company Crisis. Science Journal of Business and Management.

Vol. 4, No. 6, 2016, pp. 187-193. doi: 10.11648/j.sjbm.20160406.11

Received: September 12, 2016; Accepted: October 11, 2016; Published: November 3, 2016

\begin{abstract}
Regarding different causes which have led to the crisis in the company, its type, available assets and characteristics of the company, it is not possible to apply one of the generally accepted models, concepts or approaches for crisis solving. In spite of difference of positions, due to the characteristics of the crisis, it is however possible to describe certain measures which are most commonly applied for crisis healing by companies. Such measures can be classified in several groups. One of the most important area when the company is faced with crisis are the measures to be prepared and executed in the area of revenue and sales where the crisis is usually shown mostly as declining sales in value and/or quantity. Such measures can be: increase in sales, selection of production - sale assortment and levelling prices. In the paper the measures from the field of revenue and sales in times of acute crisis in a company are explained, together with some empirical evidence from the Slovenian business practice. The final conclusion of this paper is that the company crisis cannot be eliminated only by introducing financial measures, especially the measures in the area of revenue and sales can be critical which are unfortunately in many cases avoided or even neglected mostly due to necessary time and investment.
\end{abstract}

Keywords: Crisis, Crisis Management, Crisis Measures, Revenue, Sales

\section{Introduction}

All crises create a distressing, uncertain and worrisome situation, which endangers property as well as people, and influences established business and life flows, which is why we want to resolve this situation as soon as possible. Crises in the wider socio-economic environment directly or indirectly affect the position of individual companies or other organizations which may be more or less connected with the broader scope of the crisis. A crisis in one sector may have a significant negative impact on the companies from completely different sectors.

The extent of the crisis is simultaneously reflected in several areas, making it a complex or multidimensional phenomenon, affecting the economic, social, traditional, psychological and legal aspect, their contents are described in the following Table 1 . When dealing with crises it would be highly recommended to take these aspects into consideration.

Table 1. The dimensions of a crisis - crisis as a multi-aspect phenomenon.

\begin{tabular}{ll}
\hline Aspect of the crisis & Content \\
\hline & - endangers property as well as people and influences established business and life flows, \\
The economic aspect & - redistributes the positions of market participants, \\
& - changes the principles of success and increases the threshold requirements for survival. \\
The social aspect & changes the behaviour of the participants in the crisis, \\
& - redistributes the positions of individuals and certain groups in society, \\
& brings a break with previous practices - i.e. business models, structures, processes, systems, strategies and culture - \\
The traditional aspect & and starts a new business life cycle of the organization, \\
& - new foundations for the construction of the core capabilities of the organization and competition factors are required, \\
The psychological aspect & and it brings new management ideologies and approaches. \\
\hline
\end{tabular}




\begin{tabular}{ll}
\hline Aspect of the crisis & Content \\
\hline & promoting the culmination of problems of the organization with only two possible solutions - the ruin or survival, \\
- resulting in a change in the "psychological profile" of the organization and its members, \\
- incidence of disease symptoms of the organization and its members. \\
- requires a greater consideration of additional specialized laws and implemented policies, primarily of obligation, \\
equity and insolvency law, \\
- a more strict compensation and social responsibility of the management, \\
- draws the functioning of the organization closer to the edge of legality and legitimacy.
\end{tabular}

A crisis is a short-term undesired, unfavourable and critical situation in a company (organization), directly endangering the existence and further development of this organization and is caused by an intertwined and simultaneous action of both external and internal sources ([1], [2]; cf. also [3], [4], [5], [6], [7], [8], [9], [10], [11], [12], [13], [14], [15], [16], [17], [18]).

The purpose of this paper is to stress the importance of introducing not only financial measures in a company in crisis but also the combined measures in the area of revenue, sales and marketing. At first side this can be quite understandable, however, in many cases this area is avoided or even neglected due to the fact that a company in crisis has no available resources and time which are needed in order to stop a decline in sales and then transform it into growth, what can take a longer period of time and certain investments with time-delayed results. To find out in which extent the companies in crisis implement measures in the area of revenue and sales as a part of the changed or new business model the selection of 163 Slovene companies in crisis in the period of 2009-2014 was investigated. We recognize the limitations of the research and that the financial restructuring plans, from which were obtained the information, are not necessarily the actual strategic business plans and therefore may not include all the short-term measures envisaged.

\section{Special Characteristics of the Management of Companies in Crisis}

Crisis management comprises planning, organizing, directing and monitoring companies (organizations) experiencing difficulties that directly endanger their existence and further development and its purpose is to stop negative trends by achieving a drastic change and providing the foundation for redevelopment.

The divergence of measures is not only reflected in the time dynamics of the anticipated outcome of the applied measures, but also by the profitability-survival relation, since the company undergoing an acute crisis does not follow the goal of a positive operational outcome during the rehabilitation phase, but firstly the short-term goal of survival which probably results in a negative outcome, and the entityparts relation where specific parts of the company are in a better shape than others; however, the solution must be prepared for the company as a whole (potential restructuring of assets must be taken into consideration), for which a successful balance must be established.

Crisis recovery in a company can only be successful if applied on all business levels of the company and it is therefore essential during recovery (reorganization) to ensure the simultaneous implementation of measures for solving the crisis in two basic areas, namely (cf. [19], [20]): business (substantive, operative) recovery, financial recovery.

Although a crisis in a company is directly reflected in the financial area (insolvency, deep debts, negative cash flow, etc.), it is actually only the result of developments in other (substantive) areas. Recovery projects are thus frequently focused only on solving financial problems, instead of directing attention to other areas, which are being neglected ("we could solve the crisis with additional financial resources"). For example, financial consolidation alone cannot bring positive results, if the product/service range is outdated, if excessive costs are being generated, if key personnel have left the company, if product quality is questionable etc.

Considering the variety of reasons causing the crisis, the type of crisis, available resources and the specifics of a company, no general model, concept or approach for solving a crisis is available. A latent crisis cannot be solved by adopting the same measures as in the event of an acute crisis. Or a strategic crisis by using the same approach as in the case of a liquidity crisis. We will also not attempt to solve problems in realizing development goals the same way we solve a stagnant crises. In a small company different principles and guidelines are applied in comparison to a large company system and the actions taken in a service company are different from those taken in a manufacturing company. Generally, the applied measures for a corporate enterprise and for a non-profit organization will differ. Because of the diversity and complexity of each individual crisis there is therefore no general recipe or formula.

\section{Different Measures Instead of Generally Accepted Guidelines for Crisis Solving}

Regarding different causes which have led to the crisis in the company ([21], [22], [23], [24], [25], [5], [26], [13], [27], [28], [29], [30], [31], [32], [18], [33], [34], [35]), its type, available assets and characteristics of the company, it is not possible to apply one of the generally accepted models, concepts or approaches for crisis solving. Different principles and guidelines of proceedings will be applicable in a small company in comparison with a large business system, accordingly, proceedings in a service company will differ from those in a production one. Measures, as a rule, will be 
different also when comparing a profitmaking company and a non-profit organisation. Even before a company starts to deal with crisis healing, it must, in any case, examine and determine the influence of the which had led to the emergence of the crisis, otherwise it will not be possible to achieve the desired effect. In spite of difference of positions, due to the characteristics of the crisis, it is however possible to describe certain measures which are most commonly applied for crisis healing by companies.

a) Management and organisational measures:

- replacement of the management (those who have provoked the crisis cannot heal it, since such a state of affairs usually exceeds their capabilities, their methods and style of managing have proved to be inappropriate);

- centralized managing (the authoritative managing in a period of crisis is more effective than the cooperative type, the crisis manager explicitly takes over all the responsibility for centralized business decisions;

- changed and adjusted organisation (network and apparently chaotic organisation prevails which is based on project-type solving of problems);

- effective communicating (bothways: among stakeholders within the company and between the company and its surroundings; the company is to enforce such a policy of communications which will be based upon thoughtful and reports prepared in advance).

b) Financial measures:

- insuring liquidity (it is more important to insure receive sufficient in-flow and, in this way, preserving at least minimal liquidity rather than balance sheet success);

- restructuring of external funding (extending due dates, replacing existing obligations regarding creditors with new ones, cut of due interests, conversion of debts with ownership stakes, providing new creditors for development, limiting long-term investments and advancing smaller short-term investments).

c) Expenditure measures:

- reducing various types of costs (the structure of costs is to be analyzed, the costs are to be defined and possibilities of cost reducing are to be assessed), however, in connection with the endeavour for increase in sales.

d) Staffing measures:

- decrease of the number of employees (in many cases a decrease of the number of employees has sadly been the only measure used by the management; if other measures for business and financial improvement do not follow - are not carried out at the same time, the operational state will remain unsuccessful and the only victims are dismissed workers - in this case the method of downsizing is not justified);

- replacement of middle and lower management (particular holders of management positions do not measure up to success criteria set up by the new appointed manager; replacements are carried out in accordance with the better successor principle; the replacement is to take place only when a new manager, who fulfils new requirements, is in place);

- acquirement of new staff (business practice has shown that a crisis team is in most cases set up on basis of the reputation of the manager with whom others are prepared to work, while giving up other short term benefits).

e) Measures in the area of revenue and sales: explained in the following chapter.

The described measures for crisis healing can only be used as guidelines for preparation of company improvement programmes. Since it usually deals with deep, radical and dramatic measures, a particularity ensues in the managing the crisis healing that manifests itself in (inter alia) required sacrifices that companies must endure in order to escape from the threat of a winding-up.

\section{Revenue and Sales Measures}

\subsection{Stemming a Decline in Sales or Increasing Sales}

A decline in sales and revenue is expected during a crisis and can represent one of the most important symptoms of crisis [36]. Symptoms are signals (signs) that can indicate a possible crisis in a company or foresee one. Ensuring a sufficient revenue level is therefore critical; however, the main problem is that a decline in sales must first be stopped and then transformed into growth, which can take a longer period of time and certain investments with time-delayed results, whereas a company in acute crisis has only a limited amount of time and limited resources for investing in the market and new programmes. It is even worse when the rationalization of operations or cost reduction takes a long time to take effect. Immediate efforts to increase sales, which are practically the basis of a company's existence, are therefore essential. However, they must be carefully selected.

It is usually not possible to improve sales without an appropriate marketing approach or intensified marketing activities, which will reduce the time spent at the office on account of field visits to buyers. It is important to differentiate between the measures aimed at securing shortterm profits and inflows and those geared towards the long term and focused on development. Occasional careful marketing communication can have a positive public impact, as a company in crisis is often subject to rumours about it discontinuing sales, collapsing or going bankrupt. Communication with customers can help repair any damage to the organization's reputation [37]).

An assessment of sales opportunities (as a part of selfassessment scorecard, [38]) is fundamental to the planning of other business measures. Once a realistically achievable level of sales (revenues) has been estimated for a given period, taking into account all the measures that can be taken in this regard, the operating costs need to be adjusted accordingly. If the costs cannot be lowered below an achievable level of 
sales, the continued existence of the company is doubtful, as it does not have a sufficiently developed core business to at least conditionally (subject to the implementation of other measures) generate positive results (operating profit). In such a case there is rather a fundamental strategic business problem instead of a short-term problem of crisis management.

Stopping the decline in sales is an immediate short-term measure, whereas increasing sales is a more mid-term measure, due to the time gap between the initial activities and inputs on one hand and the actual results on the other, which can be contradictory to the efforts of ensuring liquidity resources for establishing a minimal financial solvency. That is why in this context companies are more likely to opt for the form of sales increase that will ensure an immediate or fast positive cash flow.

Although the crisis "forces" a company to take short-term measures and the efforts to increase sales revenues are actually mid-term measures (in the short-term only produce more costs), these mid-term measures must be implemented at the very beginning of the company's recovery project. The sooner actions to increase sales begin, the sooner the results will be visible.

While it is indeed necessary to begin resolving a crisis with short-term solutions, it is true that this is only the first step, which is essential but on its own insufficient for the reorganization of a company and must be supported by activities associated with further development for post-crisis business. For example, short-term incorrectly directed marketing strategies can therefore cause long-term problems and damage the value of the programmes or even the entire company (e.g. reckless cost reduction to reach at least partial sales stabilization, a decrease in quality to cheaper materials). Because the image of the company and its products can suffer in a crisis, the main focus must be aimed at product quality and the correction of any eventual faults in the product.

\subsection{Pruning the Product and Service Portfolio}

During a crisis, where the top priority is to resolve the situation threatening the company's existence, there is usually neither time nor opportunity to thoroughly restructure the product and service portfolio and market strategy, which is better reserved for the stage of revitalization following the resolution of the acute crisis. It is possible, however, to prune the existing portfolio and boost the sale of products and services that are the most favourable for the company in terms of profitability, value added, the available technological, manufacturing and human resources and their impact on cash flow, while discontinuing the sale of those causing business process failure and inefficiency, providing, of course, that the market permits it. To ensure at least minimal solvency, the focus will often be on products and services that can immediately generate inflows that exceed the outflows, i.e. a positive cash flow.

Pruning the product and service portfolio often means focusing on key opportunities and offerings, whereas the company will spend less effort dealing with ancillary and complementary lines or even sell them off or discontinue them, as a company in crisis simply cannot dedicate sufficient resources to non-core lines. Since the discontinuation of less favourable products and services (narrowing/cutting down lines) is almost always associated with downsizing, both measures need to be properly coordinated (impact on fixed costs).

Pruning the product and service portfolio is not an easy task. Problems with the product and service portfolio are among the most difficult challenges of crisis management. Measures in this area should be supported by an appropriate information system that provides a breakdown of costs by cost object. The proportion of costs that cannot be directly attributed to individual cost objects is rapidly increasing as a result of technological advancement, resulting in an increase in the level of arbitrariness and associated errors in cost allocation and the determination of the cost price of products and services. Inaccurate information on costs can quickly lead to inappropriate business decisions.

Pruning product and service lines also leads to pruning customers (or markets), as it is best to focus on key customers and systematically prune the rest.

Focusing on key activities and lines is thus a short-term measure aimed at stemming negative trends in acute crises and needs to be followed by product portfolio and marketing restructuring, whose positive impact will normally only become apparent in the long term. Once the company's negative trends have been stemmed and the acute crisis brought under control, the product portfolio and marketing restructuring can be implemented on the basis of carefully conducted studies with consideration of long-term market prospects and the company's own capacities (market repositioning). The general strategic product and market focus needs to be geared towards boosting the production and sale of products with a higher value added.

\subsection{Increasing or Reducing Prices and Modifying Other Terms of Sale}

Improving liquidity and solvency is essential in an acute crisis. This includes securing a positive cash flow, which can be done in a variety of ways and combinations (e.g. prioritizing sales and production to better-paying customers, [36]). Cash flow is most easily improved by modifying the conditions of sale and purchase, which includes increasing prices. The cost savings associated with pruning product lines and markets will come with a certain delay, and an even longer delay can be expected in efforts to increase sales and revenue.

An increase in prices will have an effect similar to an increase in sales, reflecting directly in higher revenue. However, this measure can be very difficult to implement, as it normally requires the consent of the customers. Regardless, commercial practice has shown that companies in crisis frequently neglect or simply forget to modify their pricing policies even though this is a perfectly reasonable measure given the constantly rising prices of raw materials and is 
normally acceptable to customers. Pricing-related measures are therefore often limited to the simplest measure, i.e. reducing prices to increase sales and inflows, which can lead to extremely negative consequences later on, when the crisis has been resolved and the company once again begins to grow. It is a fact that a price increase will require delicate negotiations with customers, which can sometimes be unpleasant and can even jeopardize well-established relationships. Whether a company is able to increase its prices depends on its negotiating skills and the position of its products (low or high demand). Product-service combinations (multiple services added to a tangible product; an improved "package") offer more room for price increases, as competitive services are more difficult to compare with each other.

An innovative pricing policy should therefore not be based solely on price reductions (certain customers are still willing to pay more). A well-thought-out pricing policy also requires proper cost management, yet small entrepreneurs in particular neglect to determine and break down their operating costs and ascertain their impact on pricing and sales, which naturally makes it difficult to determine prices and other terms and conditions of sale in a systematic manner. Massive price reductions should be avoided at all costs, as they hinder regrowth after the crisis is resolved. Pricing is therefore one of the most important issues in a crisis and needs to be carefully thought out to prevent an opposite effect later on, in the growth stage. The matter of pricing is less delicate during times of expansion, however, when the higher demand makes up for minor errors in pricing policies.

Products that have been in stock for a prolonged period of time and could not be sold due to their unacceptable price are now best sold at an attractive reduced price, and though, if the products have not been written off (i.e. their book value has not been adjusted), this can result in accounting losses (extraordinary expenses, devaluation), it can also have a positive impact on liquidity and cash flow, which, in turn, will provide the urgently needed recovery (bridging) funds. In such sales, the costs of keeping funds tied up in inventory (taking into account the costs of any bank loans), security, storage and the ageing and potential obsolescence of the products should be weighed against their realistic potential to sell in the future, when they are even older.

However, the terms of sale include other components in addition to prices, such as payment terms, packaging and labelling costs, transport and insurance clauses (Incoterms), minimum quantity restrictions, joint marketing campaign costs, payment instruments, security instruments, obtaining various licences and certificates, etc. All these trading terms must be renegotiating. Whereas prices are always at the centre of every negotiation, less attention is given to the option of modifying other terms and conditions of sale (purchase), the benefits of which can far outweigh the negative impact of price reductions, especially in international trade. Yet practice has shown that companies often fail to appreciate how modifying the terms and conditions of sale can improve their position as sellers (buyers) as well as their cash flow.

\section{Empirical Evidence}

Previous studies of Slovenian business practices ([39], ([40]) have found that companies in receivership rarely choose to modify their business models (a system of interconnected and interdependent activities that determines the way the company "does business" with its customers, partners and vendors, [41], the way the company creates and delivers value to a set of customers at a profit, [42], [43], which would turn currently inefficient business practices into a successful operation and grant the company its further survival and development (cf. [41]). As mentioned earlier crisis recovery cannot be successful if it is not applied simultaneously in business (substantive) and financial areas (e.g. ([19], ([20]). To determine in which extent the measures in the area of revenue and sales as a short-term part of improved or changed business models are introduced in companies in crisis, the measures were researched which had been planned or implemented by the companies in an acute crisis in Slovenia between 2009 and 2014 and attempted to solve the crisis with an insolvency procedure of a compulsory arrangement (in-court restructuring, debtor in possession proceedings), started on their proposal by the authorized court (the list available at www.ajpes.si/eobjave). If bankruptcy is a method of solving an out of control crisis, then a compulsory arrangement is a method of recovery.

Out of 163 studied cases of companies in compulsory arrangement, only $14(8.6 \%)$ included in their key recovery measures the introduction of the new business model with specified short-term measures in the area of revenue, sales and marketing which should represent a healthy fundament for temporary survival and further successfulness and as many as $91.4 \%$ of companies focused only on the various forms of financial restructuring (without any serious changes in business orientation and operations in the area of revenue and sales). Of particular interest to this paper is the finding of one of those studies that nine out of the 163 companies included in the sample had successfully completed a financial restructuring or negotiated an arrangement with their creditors but then went bankrupt within nine months, invariably because they did not take adequate measures in relation to revenue and sales, approached the issue incorrectly or failed to formulate proper strategic goals.

\section{Conclusion}

The extent of the crisis is simultaneously reflected in several areas, making it a complex or multidimensional phenomenon, affecting the economic, social, traditional, psychological and legal aspect. One of the most important area when the company is faced with crisis are the measures to be prepared and executed in the area of revenue and sales where the crisis is usually shown mostly as declining sales in value and/or quantity. Such measures can be increase in 
sales, selection of production - sale assortment and levelling prices. A decline in sales and revenue is expected during a crisis and represents one of the most important symptoms or even causes of the crisis. However, the main problem is that a decline in sales must first be stopped and then transformed into growth, which can take a longer period of time and certain investments with time-delayed results when the company in crisis has no available resources and time, therefore management often wants to avoid the measures in the area of revenue and sales. Immediate efforts to stop decline and then to increase sales are practically the basis of a company's existence.

Nine out of the 163 studied cases of Slovenian companies in acute crisis between 2009 and 2014 also completely neglected to take any measures in relation to revenue and sales (as a part of the changed or new business model) whatsoever and consequently went bankrupt less than a year after exiting receivership. Only from financial restructuring a distress company cannot ensure its further existence and development. A well prepared and executed compulsory arrangement is often a necessary, yet insufficient condition for achieving a drastic change and ensuring re-development in a company, when, especially, the measures in the area of revenue and sales will be needed.

\section{References}

[1] Dubrovski, D. (2004), 'Peculiarities of Managing a Company In Crisis', Total Quality Management \& Business Excellence, Volume 15, Number 9-10, pp. 1199-1207.

[2] Dubrovski, D. (2011), Razsežnosti kriznega managementa. Mednarodna fakulteta za družbene in poslovne študije, Celje.

[3] Barnett, C. K. and Pratt, M. G. (2000), 'From Threat-Rigidity to Flexibility: Toward a Learning Model of Autogenic Crisis in Organizations', Journal of Organizational Change Management, Volume 13, pp. 74-88.

[4] Barton, L. (1993), Crisis In Organizations. Cincinnati, SouthWestern.

[5] Crone, A. (2007), 'Die Unternehmenskrise', in Crone, A. and Werner H. (Eds.), Handbuch modernes Sanierungsmanagement, München, Franz Vahlen.

[6] Fearn-Banks, K. (2011), Crisis communications. Routledge, New York.

[7] Fink, S. (1986), Crisis Management. Amacom, New York.

[8] Grünert, T. (2007), Mergers \& Acquisitions in Unternehmungskrisen. Deutscher Universitäts-Verlag, Wiesbaden.

[9] Heath, R. (1998), Crisis Management for Managers and Executives, Financial Times, Pitman Publishing, London.

[10] Hermann, Ch. F. (2008), 'Some Consequences of Crisis Which Limit the Viability of Organizations', in Boin, A. (Ed.), Crisis Management, Volume 2. Sage, Los Angeles.

[11] Homel, U., Knecht, Th. C. and Wohlenberg, H. (2006), 'Sanierung der betrieblichen Unternehmenskrise', in Homel,
U., Knecht, Th. C. and Wohlenberg, H. (Eds.), Handbuch Unternehmensrestrukturierung, Dr. Th. Gabler/GWV, Wiesbaden.

[12] James, E. H. and Wooten, L. P. (2010), Leading Under Pressure. Routledge, New York.

[13] Kraus, G. and Becker-Kolle, Ch. (2004), Führen in Krisenzeiten. Gabler, Wiesbaden.

[14] Lalonde, C. (2008), Organiser la réponse a la crise, L'Harmattan, Paris.

[15] Lerbinger, O. (1997), The Crisis Manager, Lawrence Erlbaum Associates, Mahwah.

[16] Neubauer, M. (1999), Krisenmanagement in Projekten. Springer, Berlin.

[17] Roux-Dufort, Ch. (2003), Gérer et décider en situation de crise. Dunod, Paris.

[18] Slatter, S. (1987), Corporate Recovery. A Guide to Turnaround Management. Penguin Books, London.

[19] Kraus, K.-J. and Gless, S.-E. (2004), 'Unternehmensrestrukturierung/-sanierung und strategische Neuausrichtung', in Buth, A.K. and Hermanns, M. (Eds.), Restrukturierung, Sanierung, Insolvenz, Verlag C. H. Beck, München.

[20] Seefelder, G. (2007), Unternehmenssanierung. SchäfferPoeschel, Stuttgart.

[21] Bellinger, B. (1962), 'Unternehmungskrisen und ihre Ursachen', in Handelsbetreib und Marktordnung, Gabler, Wiesbaden.

[22] Bibeault, D. B. (1999), Corporate turnaround: how managers turn losers into winners. Beard Books, Washington.

[23] Boeckenfoerde, B. (1993), 'Kriza podjetja', Pristop, Number 2, pp. 33-40.

[24] Boin, A. (2008), 'Fundamentals of crisis development and crisis management: an introduction to critical crisis readings' in Boin, A. (Ed.), Crisis management, Volume 1, Sage, Los Angeles.

[25] Crandall, W. R., Parnell, J. A. and Spillan J. E. (2014), Crisis management. Sage, Los Angeles.

[26] Harz, M., Hub, H.-G. and Schlarb, M. (2006), SanierungsManagement. Wirtschaft und Finanzen, Stuttgart.

[27] Lymbersky, Ch. (2013), 'Why do companies fail? 2014 survey results', Turnaround Management Journal, Number 2, pp. 4149.

[28] Mitroff, I., Pauchant, T. C. and Shrivastava, P. (2006), 'The Structure of man-made organizational crises: conceptual and empirical issues in the development of a general theory of crisis management', in Smith, D. and Elliot, D. (Eds.), Key readings in crisis management. Routledge, London.

[29] Müller, R. (1986), Krisenmanagement in der Unternehmung. Peter Lang, Frankfurt am Main.

[30] Pate, C. R. (1999), 'Business regeneration: early detection early intervention', in DiNapoli, D. (Ed.), Workouts \&turnarounds 2: global restructuring strategies for the next century. John Wiley \& Sons, New York. 
[31] Pümpin, C. and Prange, J. (1995). Usmerjanje razvoja podjetja. Gospodarski vestnik, Ljubljana.

[32] Richardson, B. (1994), 'Crisis management and management strategy: time to 'loop the loop'?', Disaster Prevention and Management, Volume 3, Number 3, pp. 59-80.

[33] Slatter, S. (1990), 'Je vaše podjetje zdravo?', Podjetnik, Number 3, pp. 29-33.

[34] Schellberg, B. (2008), Sanierungsmanagement. Erich Schmidt Verlag, Berlin.

[35] Wildemann, H. (2004), Sanierungsstrategien. TCW TransferCentrum, München.

[36] Lymbersky, Ch. (2014). The International Turnaround Management Standard. Version 1.5. Hamburg: Turnaround Management Society.

[37] Tucker, E (2015). Business Continuity from Preparedness to Recovery. Kidlington: Butterworth-Heinemann
[38] Zinka, C. (2010). Business Restructuring. Hoboken: John Wiley \& Sons.

[39] Dubrovski, D. (2009), Management mistakes as causes of corporate crisis, Total Quality Management \& Business Excellence, Volume 20, Number 1-2, pp. 39-59.

[40] Dubrovski, D. (2010), 'Pomembnost ugotavljanja pravilnih vzrkov za nastanek podjetniške krize', Management, Volume 5, Number 1, pp. 37-52.

[41] Amit, R., Zott Ch. (2012), 'Creating value through business model innovation', MIT Sloan Management Review. Volume 53, Number 3, pp. 41-49.

[42] Johnson, M. W. (2010), Seizing the White Space. Harvard Business Press, Boston.

[43] Kavadias, S., Ladas K. and Loch, Ch. (2016), 'The Transformative Business Model', Harvard Business Review. Number: October. 